\title{
A STUDY OF PHARMACOKINETICS OF ATORVASTATIN ON TYPE 2 DIABETIC \& DYSLIPIDEMIC BENGALI POPULATION OF INDIA AND BANGLADESH
}

\author{
SHYAMALI PAL* AND SUJOY MAJUMDAR \\ ${ }^{1}$ Eastern Diagnostics India Ltd, 13C, Mirza Ghalib Street, Kolkata- 700016, WB, India. \\ 2G.D. Diabetic Research Institute, Kolkata- 700016, WB, India. \\ *Corresponding Author: Email-shy23_pal@yahoo.co.in
}

Received: August 01, 2012; Accepted: August 07, 2012

\begin{abstract}
-
Objective: Type 2 diabetes (T2DM) is a global problem and WHO reported one million one hundred thousand deaths per year globally due to diabetes [1]. T2DM increases the mortality due to cardiovascular disease [2]. The study was designed to get an idea how the T2DM community of Bengal and Bangladesh are responding to atorvastatin, the kinetics of the improvement of lipid and diabetic status specially LDL Cholesterol (LDLC). Soybean/Sunflower oil was advised to use as a cooking medium as both the oil contains poly unsaturated fatty acid as a result would help to minimize VLDL Cholesterol (VLDLC) and triglycerides (TG).

Methods: Four hundred fifty Type 2-Diabetes Mellitus (T2DM) patients of which 400 with slightly elevated lipid profile and 50 patients were T2DM with gross dyslipidaemia were considered as study material. The patients are male and in the age group of 35-50 years. The basal lipid and diabetic profile were estimated. The medication for diabetes and dyslipidaemia were started. The patients were on strict diet regime, nonsmoker, non-alcoholic and user of white oil (soybean/sunflower) as cooking medium. They were on $10 \mathrm{mg}$ atorvastatin per day. After 6 months and after 12 months a follow up was done to get an idea about the effect of atorvastatin on the lipid profile of the patients.

Results: Both the group of patients with moderate and gross lipidemia have responded well. Even gross dyslipidemics shown improvement with $10 \mathrm{mg}$ atorvastatin per day. The diabetes profile and atherogenic profile were also improved. One tailed $P$ value of 0 to 6 months and 6 to 12 months denoted significant changes.

Conclusion: The group under study responded well to the diet and medicine regime. So, the population study indicates similar regime may be of help for T2DM and hyperlipidemics of Bengali population.
\end{abstract}

Key words- T2DM, CHD, HDLC, LDLC, Atorvastatin

Citation: Shyamali Pal and Sujoy Majumdar (2012) A Study of Pharmacokinetics of Atorvastatin on Type 2 Diabetic \& Dyslipidemic Bengali Population of India and Bangladesh. International Journal of Medical and Clinical Research, ISSN: 0976-5530 \& E-ISSN: 0976-5549, Volume 3, Issue 6, pp.-203-206.

Copyright: Copyright@2012 Shyamali Pal and Sujoy Majumdar. This is an open-access article distributed under the terms of the Creative Commons Attribution License, which permits unrestricted use, distribution and reproduction in any medium, provided the original author and source are credited.

\section{Introduction}

Atorvastatin is a competitive inhibitor of HMG CoA reductase. It minimizes de-novo cholesterol biosynthesis by inhibiting the rate limiting step of catalysis of reduction of 3-hydroxy methyl glutaryl CoA to mevalonate [2]. Inhibition of cholesterol synthesis increases expression of low density lipoprotein cholesterol in hepatocytes decreasing concentration of LDLC in blood [3]. So, atorvastatin is having dual action

- Inhibition of De Novo Total Cholesterol (TC) biosynthesis [2].

- Lowering of blood LDLC concentration [3].

It has been observed that the risk of coronary heart disease (CHD) is more in diabetics \& hyperlipidemics than in euglycemics with hyperlipidemia [4]. In the present study 450 T2DM patients (400 moderate and 50 gross dyslipidemics) were taken and they were on $10 \mathrm{mg}$ atorvastatin after basal diabetic \& lipid profile having been tested. Follow up on 6 months and 12 months were done to get an idea to what extent the fixed dose of atorvastatin is reducing the lipid profile.

As India is a country of varying food habits, stature and life style so specifically Bengali population of both India and Bangladesh were chosen as study material staple food being rice and Sweetwater fish.

The patients under trial were requested to use cooking oil of similar brand to rule out the difference in triglycerides level due to use of cooking medium of different constituents [5]. Female patients were not been included in the study as reference interval of HDLC is different from that of male patients and a separate study design of menstrual and post-menopausal women were needed [6].

\section{Materials and Methods \\ Study Population}

Four hundred fifty (400 moderate \& 50 gross dyslipidemic) male diabetic patients of the age group 35-55 years were chosen as study population. The patients detected as T2DM and dyslipidemic 
for the first time. So, they were not offered any medication beforehand. The patients were non-smokers, non-alcoholic. On 0 month 383 patients with T2DM \& moderate dyslipidemia and all the 50 T2DM patients with gross dyslipidemia were turned up. Consents from the patients were obtained.

On 6 months 366 moderate dyslipidemics \& all gross dyslipidemics with T2DM were turned up for follow up.

On 12 months the number of gross lipidemics remained same. All of them completed the trial. From moderate dyslipidemics 325 out of 366 turned up for follow up.

The percent turn up is 91.5 on 6 month, 81.25 on 12 months for moderate dyslipidemics and $100 \%$ for gross dyslipidemics.

\section{Study Design of the Parameters}

Parameters considered to be studied are fasting and post prandial glucose, HbA1c Microalbumin-Creatinine Ratio (MCR), apolipoproteinB (apoB), TC, HDLC, LDLC, triglycerides (TG) basal metabolic index (BMI) and atherogenic index ( $\mathrm{Al})$ of which $\mathrm{Al}$ is calculated parameter.

Basal values of all the parameters were estimated. Follow up results studied after 6 months and 12 months. Follow up parameters remained same.

\section{Diagnosis and Laboratory Measurement}

The patients are non-smoker, non-alcoholic and user of only white oil as cooking medium. By habit, the patients were non vegetarian and accustomed to well-cooked Sweetwater fish and rice. Blood glucose lipid profile (TC, HDLC, LDLC, VLDLC, TG), HbA1c, MCR and $\mathrm{apoB}$ were estimated in automated biochemistry analyser. All the kits were IFCC; NGSP [7-14] approved and had proper traceability records.

The laboratory guideline for quality control i.e., EQAS, unity realtime programme (BIO-RAD) have been followed. So, authenticities of the reports are well approved.

\section{Ethical issues}

The patient's consents have already been taken. The hospital ethical committee has approved the study.

\section{Guideline for Sample Collection}

The blood samples were taken after 12-13 hrs. fasting in evacuated container with proper preservative and not in stressed condition. Post prandial blood sample taken $2 \mathrm{hrs}$ after meal as suggested by dietician (Table-1).

\section{Clinical Management}

All the patients were on atorvastatin (10mg/day) \& diet as per table -1 for one year after basal levels were estimated. But as they are diabetic also, the routine management of diabetes is as follows:

Patients with $\mathrm{HbA} 1 \mathrm{c}$ over $6.5 \%$ were on hypoglycaemic drug Metformin. $\mathrm{HbA} 1 \mathrm{c}$ within the range of $7-8 \%$ were on Sulphonylureas like Glibenciamide, Gliclazide, Glipizide. Thiazolidinediones like Rosiglitazone, Pioglitazone were also given as treatment. The patients having $\mathrm{HbA} 1 \mathrm{c}$ over $8 \%$ were treated with Human Insulin. The dosage was adjusted as per clinical situation by the Endocrinologist.

\section{Statistical analysis}

Data for normally distributed values were presented as mean $\pm 2 S D$. Patients with moderately elevated lipid profile and the same with gross dyslipidaemia were analysed as a different group. Mean $\pm 2 S D$ of the distributed values were analysed. One tailed $p<0.05$ denoted statistical significance [15].

\section{Results and Discussion}

Fasting and post prandial glucose, $\mathrm{Al}$ and BMI has drastically improved by $0-6$ months (Table- $1 \mathrm{~A} \& 1 \mathrm{~B}$ ). From 6-12 months seems to be the maintenance period where the values are on the lower side but rate of decrease is slow and steady. HbA1c and MCR show steady decreasing pattern from basal to 12 months. The overall impression is the population under study is following the diet and medicine protocol and the design suited well (Table- $1 \mathrm{~A}$ \&1B).

Table 1A-Serial Studies of Diabetic and Atherogenic Index of Type 2 DM \& Moderate dyslipidemia

\begin{tabular}{|c|c|c|c|c|}
\hline Parameter & Biological Reference Interval & $\begin{array}{c}0 \text { months } \\
\mathrm{N}=383\end{array}$ & $\begin{array}{c}6 \text { months } \\
\mathrm{N}=366\end{array}$ & $\begin{array}{c}12 \text { months } \\
\mathrm{N}=325\end{array}$ \\
\hline Glucose(F) & $3.85-6.05 \mathrm{mmol} / \mathrm{l}$ & $10.35 \pm 1.35^{\star}$ & $5.65 \pm 1.47^{\star}$ & $4.65 \pm 1.25^{\star}$ \\
\hline Glucose(PP) & & & & \\
\hline $\mathrm{HbA1c}$ & $\begin{array}{l}\mathrm{f} H \mathrm{Hb} \\
\mathrm{g} / \mathrm{ma} \text { (normal) }\end{array}$ & $7.3 \pm 0.8^{*}$ & $6.4 \pm 1.4^{*}$ & $5.8 \pm 0.7^{\star}$ \\
\hline MCR & $\begin{array}{l}\text { Upto } 300 \mu \mathrm{mg} / \mathrm{mg} \text { Microalbuminurea, } \\
\geq 300 \mu \mathrm{g} / \mathrm{mg} \text { macroalbuminurea }\end{array}$ & $265 \pm 78.6^{*}$ & $125 \pm 43^{*}$ & $60 \pm 21.4^{*}$ \\
\hline $\mathrm{Al}$ & Upto 4 & $4.5 \pm$ & $3.5 \pm 1.05^{*}$ & $3.25 \pm 0.48^{*}$ \\
\hline BMI & $18.5-24.9$ & $24.4 \pm 4.5^{*}$ & $22.5 \pm 2.61^{*}$ & $19.5 \pm 1.45^{*}$ \\
\hline
\end{tabular}

${ }^{*} P$ value $<0.0001$. Compared as 0-6 months and 6-12 months

Table 1B-Serial Studies of Diabetic and Atherogenic Index Type 2 DM \& Gross dyslipidemia

\begin{tabular}{|c|c|c|c|c|}
\hline Parameter & Biological Reference Interval & $\begin{array}{l}0 \text { months } \\
\mathrm{N}=50\end{array}$ & $\begin{array}{l}6 \text { months } \\
\mathrm{N}=50\end{array}$ & $\begin{array}{c}12 \text { months } \\
\mathrm{N}=50\end{array}$ \\
\hline Glucose(F) & $3.85-6.05 \mathrm{mmol} / \mathrm{l}$ & $9.4 \pm 2.55^{*}$ & $8.65 \pm 2.35^{*}$ & $5.75 \pm 1.25^{*}$ \\
\hline Glucose(PP) & $3.85-7.73 \mathrm{mmol} / \mathrm{l}$ & $10.2 \pm 3.65^{*}$ & $6.75 \pm 2.35^{*}$ & $6.05 \pm 2.22$ \\
\hline $\mathrm{HbA1c}$ & $\begin{array}{l}4.2-6.2 \% \text { of } \mathrm{Hb} \\
\text { Below } 30 \mu \mathrm{g} / \mathrm{mg} \text { (normal), }\end{array}$ & $9.5 \pm 0.85^{*}$ & $8.4 \pm 1.4^{*}$ & $7.0 \pm 0.7^{*}$ \\
\hline MCR & $\begin{array}{l}\text { Upto } 300 \mu \mathrm{g} / \mathrm{mg} \text { Microalbuminurea, } \\
\geq 300 \mu \mathrm{g} / \mathrm{mg} \text { macroalbuminurea }\end{array}$ & $545 \pm 105^{*}$ & $385 \pm 43^{*}$ & $75 \pm 21.4^{*}$ \\
\hline $\mathrm{Al}$ & Upto 4 & $4.5 \pm 1.75$ & $4.0 \pm 1.05$ & $3.65 \pm 0.5$ \\
\hline BMl & $18.5-24.9$ & $27.4 \pm 4.5^{\star}$ & $24.5 \pm 2.61^{*}$ & $20.5 \pm 1.35^{*}$ \\
\hline
\end{tabular}

${ }^{*} P$ value $<0.0001$. Compared as 0-6 months and 6-12 months

The lipid profile study of both the groups show a steady decline in TC and LDLC in both the groups but rate of decrease is more in gross dyslipidemics than normolipidemics (Table- 2A \& 2B). The slope of LDLC and TC are parallel showing the effect of atorvastatin on TC synthesis and on LDL receptor on hepatocytes (Graph1). No direct effect on HDLC is observed in the study. But in gross dyslipidemics HDLC on 12 months study is observed to be less than 6 months which may only be attributed to decrease in TC biosynthesis (Graph-1). The parallel decrease in TC and LDLC alongwith rise in HDLC and decrease in VLDLC indicates the already established idea of dual effect of atorvastatin (Graph-1 \& 2). Both gross and moderate dyslipidemics used $10 \mathrm{mg}$ atorvastatin per day. After steady decline the slope became steady for both TC and LDLC in the interval of 6 months to 12 months (Graph-1). Hence, it seems atorvastatin is a safe medicine of maintainance. The established TG lowering oil is olive oil. But as it is not available locally, so the oil containing poly unsaturated fatty acids like soybean/sunflower oil has been suggested. A drastic lowering of TG in 
both the groups was observed along with lowering of VLDLC. The rate of decrease of apolipoprotein $B$ is directly proportional to LDLC. To summarize, the good effect of atorvastsatin have been reflected in LDLC, apolipoprotein B and TC. The lowering of other factors like TG, VLDLC may be attributed to cooking medium (Table- 2A \& 2B, Graph- 2). But 6 months to 12 months (Graph- 2) are indicative of efficiency of atorvastatin as medicine of maintenance and the slopes reflects the concern of the community.

Table 2A-Serial Studies of Lipid Profile of Type 2 DM \& Moderate dyslipidemia

\begin{tabular}{|c|c|c|c|c|}
\hline Parameter & $\begin{array}{l}\text { Biological Reference } \\
\text { Interval }\end{array}$ & $\begin{array}{l}0 \text { month } \\
\mathrm{N}=383\end{array}$ & $\begin{array}{l}6 \text { month } \\
N=366\end{array}$ & $\begin{array}{l}12 \text { month } \\
N=325\end{array}$ \\
\hline $\mathrm{TC} \mathrm{mmol} / \mathrm{l}$ & $\begin{array}{l}\text { Desirable upto } 5.18 \\
\text { Borderline upto } 6.5 \\
\text { High } \geq 6.5\end{array}$ & $5.05 \pm 1.05^{*}$ & $4.66 \pm 1.11^{*}$ & $4.2 \pm 1.06^{*}$ \\
\hline HDLC mmol/l & $\begin{array}{l}0.9-1.55 \\
\text { Desirable } \leq 3.36\end{array}$ & $0.99 \pm 0.23^{*}$ & $1.38 \pm 0.17^{*}$ & $1.4 \pm 0.25$ \\
\hline LDLC msmol/l & $\begin{array}{l}\text { Borderline upto } 3.38 \\
\text { High } \leq 3.38\end{array}$ & $3.66 \pm 0.43^{*}$ & $2.46 \pm 0.52^{*}$ & $2.38 \pm 0.22$ \\
\hline VLDLC mmol/l & $0.31-0.77$ & $1.75 \pm 0.39^{*}$ & $1.55 \pm 0.15^{*}$ & $1.35 \pm 0.49^{*}$ \\
\hline TG mmol/l & Upto 1.7 & $4.9 \pm 0.65^{*}$ & $2.2 \pm 0.8^{*}$ & $1.75 \pm 0.44^{*}$ \\
\hline ApoB g/l & $0.5-1.6$ & $1.31 \pm 0.15^{*}$ & $1.18 \pm 0.25^{\star}$ & $0.98 \pm 0.11^{*}$ \\
\hline
\end{tabular}

${ }^{*} P$ value $<0.0001$. Compared as 0-6 months and 6-12 months

Table 2B-Serial Studies of Lipid Profile Type 2 DM \& Gross dyslipidemia

\begin{tabular}{|c|c|c|c|c|}
\hline Parameter & $\begin{array}{l}\text { Biological Reference } \\
\text { Interval }\end{array}$ & $\begin{array}{c}0 \text { month } \\
\mathrm{N}=50\end{array}$ & $\begin{array}{c}6 \text { month } \\
\mathrm{N}=50\end{array}$ & $\begin{array}{c}12 \text { month } \\
N=50\end{array}$ \\
\hline $\mathrm{TC} \mathrm{mmol} / \mathrm{l}$ & $\begin{array}{l}\text { Desirable upto } 5.18 \\
\text { Borderline upto } 6.5 \\
\text { High } \geq 6.5\end{array}$ & $9.7 \pm 1.3^{*}$ & $7.4 \pm 2.6^{*}$ & $6.0 \pm 1.22^{* *}$ \\
\hline $\mathrm{HDLC} \mathrm{mmol} / \mathrm{l}$ & $\begin{array}{l}0.9-1.55 \\
\text { Desirable } \leq 3.36\end{array}$ & $1.03 \pm 0.23$ & $1.07 \pm 0.25^{\star \star}$ & $0.93 \pm 0.15^{\star \star}$ \\
\hline LDLC msmol/l & $\begin{array}{l}\text { Borderline upto } 3.38 \\
\text { High } \leq 3.38\end{array}$ & $4.1 \pm 0.91$ & $3.75 \pm 0.9$ & $3.65 \pm 0.8$ \\
\hline VLDLC mmol// & $0.31-0.77$ & $3.75 \pm 0.57^{*}$ & $2.2 \pm 1.24^{*}$ & $2.38 \pm 0.8$ \\
\hline TG mmol/l & Upto 1.7 & $7.66 \pm 3.15^{\star}$ & $4.51 \pm 2.25^{*}$ & $3.2 \pm 1.86^{* \star}$ \\
\hline ApoB g/l & $0.5-1.6$ & $1.5 \pm 0.3^{\star *}$ & $1.32 \pm 0.31^{* *}$ & $1.05 \pm 0.32^{\star *}$ \\
\hline
\end{tabular}

${ }^{*} P$ value $<0.0001$. Compared as 0-6 months and 6-12 months ${ }^{* *} P$ value $<0.005$. Compared as 0-6 months and 6-12 months

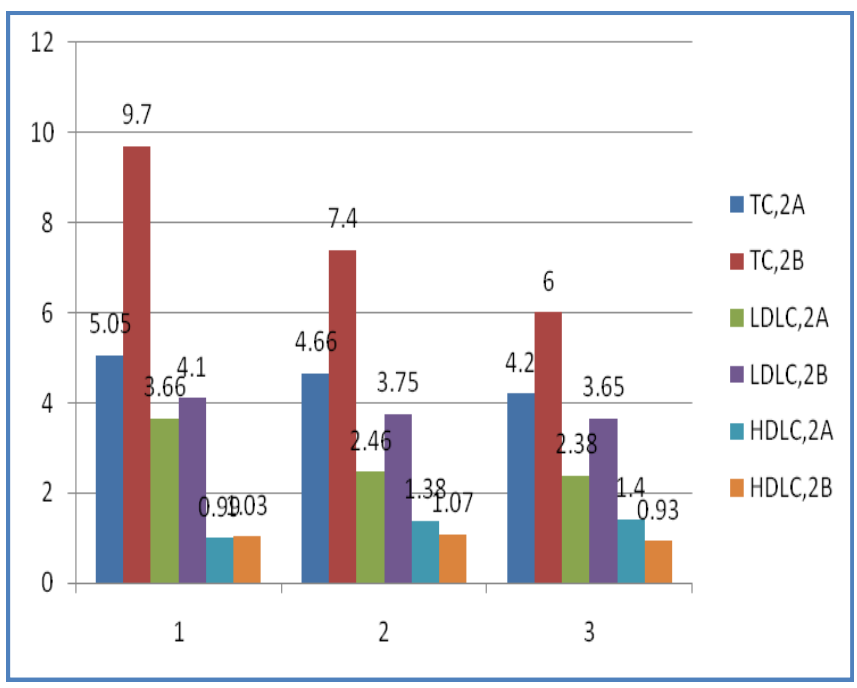

Graph 1-

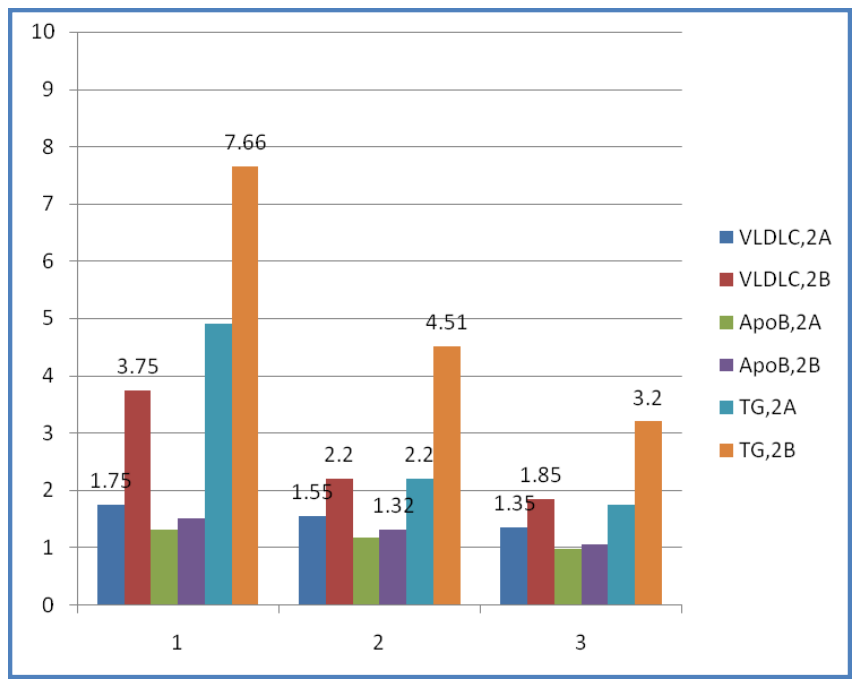

Graph 2-

The dyslipidemic community are seriously concerned and they strictly followed the medicine and diet regime (Table- 3) showing improvement in $\mathrm{Al}$ and $\mathrm{BMI}$ also. At least it may be concluded that strict regime prevented the possibility of use of statin in higher dosage. No adverse effects of medicines were reported to the Endocrinologist.

Table 3- Dietary Regime Suggested During Study Period

\begin{tabular}{ll|} 
Food Ration & Patients undergoing the study \\
Energy & $1600 \mathrm{kcal}$ \\
Protein & $78 \mathrm{gms}$ \\
Fat & $30 \mathrm{gms}$ \\
Carbohydrates & $247 \mathrm{gms}$ \\
Cereals & $230 \mathrm{gms}$ \\
Fish & $100 \mathrm{gms}$ \\
Fruits & $100 \mathrm{gms}$ \\
Fish & $100 \mathrm{gms}$ \\
Chicken & $60 \mathrm{gms}$ \\
Milk(300 ml as casein/curd) & $500 \mathrm{ml}$ \\
Oil & $20 \mathrm{ml}$ \\
Salad & plenty \\
Water & plenty \\
\hline
\end{tabular}

As the results of basal values were compared with 6 months and the same compared with 12 months one tailed t-test is used. Significant differences were observed in all the parameters except atherogenic index of gross dyslipidemics with T2DM. It seems possibly improvement in Al would have been remarkable after some more time. HDLC \& LDLC of moderate dyslipidemics are not significantly different from 6 months to 12 months as improvement has been observed earlier and then a steady maintenance is observed.

In gross dyslipidemics in first 6 months $P$ values are not significant for HDLC, LDLC and ApoB. The difference is significant but value on the lower side for HDLC at 12 months. Decrease in LDLC were not significant between 0 to 6 months and as $A p o B$ is the core protein of LDLC the change is not significant for ApoB also. Both became significant between 6 months to 12 months. The observation of VLDLC is significant at 0-6 months but insignificant from 612 months which may be attributed to its labile nature and difference in standard deviation at 12 months. 


\section{Conclusion}

In conclusion it may be said the risk factors of $\mathrm{CHD}$ and diabetic profile parameters shown significant difference from 0 to 6 to 12 months indicating proper diet (Table- 1), medicine regime, usefulness of atorvastatin so the medicine for maintenance and concern of the community for the risk factors.

\section{Acknowledgement}

The authors acknowledge the fund support of Accurex Biomedicals Pvt. Ltd. and active support of Eastern Diagnostics India Ltd.

\section{References}

[1] Beaglehole R. (2006) 19th World Diabetic Congress, 23, 12.

[2] Villa J., Prattey R.E. (2011) Curr. Diab. Res. 10(3), 173-5.

[3] McCormack T., Harvey P., Gaunt R., Allgar V., Chipperfield R., Robinson P. (2010) Int. J. Clin. Pract., 64(8), 1052-61.

[4] Grundy S.M., Benjamin I.J., Burke G.L., Chait A., Eckel R.H., Howard B.V., Mitch W., Smith S.C., Sowers J.R. (1999) Circulation, 100, 1134-46.

[5] Sabitha P., Vaidyanathan K., Vasudevan D.M. Kamath P. (2009) Ind. J. Clin. Biochem., 24(1), 76-81.

[6] Zhang X., Zhaoging S., Xinzlong Z. (2007) Neurology India, 55, $338-42$.

[7] Richmond W., Allain C.C., Poon L.S., Chan C.S., Fu P.C. (1974) Clin. Chem., 20, 470-5.

[8] Trinder P. (1969) Ann. Clin. Biochem., 6, 24-7.

[9] Gordon T., Castelli W.P., Hjortland M.C. (1974) Am. J. Med., 62, 707-14.

[10]Bachoric P.S., Ross J.W. (1995) Clin. Chem., 41, 1414-20.

[11]Kari J. (1933) Klin. Lab., 39, 991-6.

[12]Bry L., Chen P.C., Sacks D.B. (2007) Clin. Chem., 47, 153-63.

[13]Wallach J. (2007) Interpretation of Diagnostic Tests, 8th ed. 1217.

[14]Mcpherson R.A., Pincus M.R. (2007) Henry's Clinical Diagnosis and Management by laboratory Methods, 21st ed., 1405-10.

[15]Kreyszig E. (1970) Introductory Mathematical Statistics., 103, 144-6. 